\title{
The Differential Management of Financial Illegalisms: Assigning Responsibilities in the Libor Scandal
}

\section{MPIfG Journal Article}

Thomas Angeletti: The Differential Management of Financial Illegalisms: Assigning Responsibilities in the Libor Scandal. In: Law \& Society Review 53(4), 1233-1265 (2019). Wiley-Blackwell

The original publication is available at the publisher's web site: https://doi.org/10.1111/lasr.12442

The MPIfG Journal Articles series features articles by MPIfG researchers and visiting scholars published in peer-reviewed journals. Max Planck Institute for the Study of Societies (MPIfG) Cologne | www.mpifg.de

\section{Thomas Angeletti 10}

How, in a context of growing critiques of financialization, can law contribute to protecting the legitimacy of finance? This paper argues that the assignment of responsibilities between individuals and organizations plays a decisive role, using the recent Libor scandal as an empirical illustration. To do so, the paper offers a Foucauldian framework, the differential management of financial illegalisms, dedicated to the study of illegalities in financial capitalism. The comparison of the legal treatment of two manipulations of Libor, this key benchmark in financial markets, reveals how mid-level traders have been the object of criminal prosecution, while law undervalued the role of top managers and organizations. To capture how differential management is performed in practice, I analyze precisely how the conflict-resolution devices (criminal trial vs. settlement) and the social categorizations prevailing in the two manipulations of Libor favor different forms of responsibility, individual or organizational. I conclude by exploring the implications of law's relationship to financial legitimacy.

$\mathrm{F}$

or more than a decade now, the financialization of capitalism (Krippner 2011; Van der Zwan 2014) has been the locus of many critiques. Financialization has been studied sufficiently to understand how much finance has invaded our daily lives (Martin 2002), without measuring necessarily fully its ramifications. The clear causality between the rise of wages in the financial sector and the rise in income inequality in the United Kingdom (Bell and Van Reenen 2013), the United States (Volscho and Kelly 2012), and France (Godechot 2012) has put the financial sector on the spot. With the related emergence of the "1 percent," the Occupy Wall Street movement also targeted the financial sector,

I started writing this paper during a stay at the Max Planck Institute for the Study of Societies, and I thank especially Jens Beckert for his support. I benefited from reactions during successive presentations at the conferences of the Society for the Advancement of Socio-Economics, the French Sociological Association, the Law \& Society Association, and at the Finance and Society conference. Many thanks go to Tim Bartley, Natalia Besedovsky, Sebastian Billows, Marie Le Clainche-Piel, Benjamin Lemoine, Gwénaëlle Mainsant, Marcin Serafin, and to the reviewers and editors of the Law E Society Review for their generous comments.

Please direct all correspondence to Thomas Angeletti: Université Paris Dauphine, PSL Research University, Place du Maréchal de Lattre de Tassigny, 75775 Paris Cedex 16, France; e-mail: thomas.angeletti@dauphine.psl.eu 
and "We are the 99 percent" resonated close to the stock exchanges of key financial centers, such as Zuccotti Park in New York, La Défense in Paris, and London's financial district.

In particular, the extent of fraud in the financial industry has been a heated topic of public debate. For instance, the National Commission on the Causes of the Financial and Economic Crisis in the United States, established by President Barack Obama in 2009 , in its report expressed no doubt regarding the existence of fraud in the financial sector during the 2000s. The report

catalogues the rising incidence of mortgage fraud, which flourished in an environment of collapsing lending standards and lax regulation. The number of suspicious activity reportsreports of possible financial crimes filed by depository banks and their affiliates-related to mortgage fraud grew 20-fold between 1996 and 2005 and then more than doubled again between 2005 and 2009. (National Commission on the Causes of the Financial and Economic Crisis in the United States [NC] 2011: xxii)

As this report makes clear, financial fraud has been, to some extent, publicly recognized. However, despite this recognition, it seems that financial scandals continue to occur and fraud keeps happening, without generating a broader questioning of finance that could have a substantial effect on the legitimacy of financial capitalism.

How, in a historical situation characterized by a financial crisis and strong critiques of finance, are financial institutions able to remain legitimate? This paper adopts a sociological approach to this question by dissecting the contribution of law in protecting the legitimacy of financial capitalism. It argues that the assignment of responsibilities between individuals and organizations plays a key role in this matter. When courts and agencies charge and sometimes sanction financial fraud, they indeed decide which responsibilities go to individuals on one side, and which ones go to organizations on another. In the Foucauldian perspective adopted in this paper, such an assignment is conceived as an instrument for managing financial fraud, hierarchizing its forms and, ultimately, restraining the public discussion of financial scandals.

Different kinds of legal action against such fraud can indeed be discerned, between legal action targeting individuals and that targeting organizations, as recent examples illustrate. Regarding individuals, criminal prosecutions have focused primarily on traders: the Kerviel-Société Générale affair in France (Kerviel 2010), the trials against Kweku Adoboli ( $R v$ Adoboli 2012) and 
against Tom Hayes ( $R v$ Hayes 2015) in the United Kingdom, or the trial against Fabrice Tourre (SEC $v$ Tourre 2010, a civil case) in the United States. These prosecutions mostly targeted individuals in mid-level positions, frequently those who had climbed remarkably quickly but were yet far from occupying the highest positions. ${ }^{1}$ Indeed, no CEO or board member has been subject to criminal prosecution since the financial crisis (Rakoff 2014; Pontell, Black and Geis 2014).

Financial organizations have certainly been sanctioned but none has been subject to a criminal trial. Instead, the prevailing logic in the responses to the illegalisms of financial organizations is the settlement (Serverin, Lascoumes and Lambert 1987; Garrett 2014, 2016). Fligstein and Roehrkasse (2016) have shown the massive use of settlements in dealing with the widespread fraud in the mortgage securitization industry. According to a recent report, sanctions against American and European banks between 2009 and 2016 totaled more than $\$ 321$ billion $^{2}$ (BCG 2017). The recent trend is one of a rise in bank prosecutions (Garrett 2016), even though in most cases they avoid going to trial. In this respect, the originality of Jean-Stéphane Bron's documentary, Cleveland versus Wall Street (2010), lay in the organization of a trial against Wall Street as a whole.

In these circumstances, what characterizes the current situation is, on the one hand, the resurgence of settlements and fines against financial institutions and the absence of trials against them and, on the other, the criminal prosecution of individuals who occupy mid-level positions. We know that in financial matters, "equally harmful acts are not equally punished" (Snider 2011: 131). But more than unequal, this management is differential, in that it hierarchizes the forms of fraud that will end up in front of a court.

This paper examines this issue in one of the most debated financial scandals in recent years, the Libor scandal. Libor is a key benchmark in the financial industry: not only is it an indicator of borrowing possibilities between banks, but countless financial products are indexed on its value. Authorities' investigations revealed two different manipulations of Libor in 2012: the trader manipulation perpetrated by traders for their own benefit and the lowballing manipulation dedicated to protect banks' reputation in a context of credit scarcity. This paper compares legal treatment of

${ }^{1}$ Although, as the central hierarchy in the financial industry revolves around income (Godechot 2001), traders-and especially derivatives traders-occupy symbolically high positions.

${ }^{2}$ This figure underestimates the total, as it takes into account only settlements of more than $\$ 50$ million. 
these two manipulations. While the trader manipulation generated many criminal prosecutions and trials, lowballing manipulation did not generate any criminal trials until now and responsibility stayed at the level of organizations. I show therefore that the assignment of responsibilities between individuals and organizations in the Libor scandal has led to an underestimation of the role played by the highest managers in financial institutions. Moreover, by demonstrating how this assignment is performed by courts and agencies, through the use of different devices for individuals - such as criminal trials-and for organizations-such as settlements-I contend that the law contributes to protecting financial capitalism's legitimacy. Thus, by placing the issue of illegal practices in financial markets at the center of analysis, the paper argues that these practices are a constituent aspect of capitalism. ${ }^{3}$

The article is organized as follows. Below, I delineate some important conceptual and theoretical issues associated with financial fraud and explain how the "differential management of financial illegalisms" approach, elaborated on the basis of Michel Foucault's work on punishment (Foucault 1977, 2015), is a germane theoretical framework for tackling the question of the relationship between law and financial legitimacy. I then introduce the Libor case and what was at stake during the scandal. Following this, I outline the methodological and empirical foundations of my study. I successively present its main findings, showing how two manipulations of Libor ended up with radically different outcomes. I close the article by discussing implications for extant theory and future research.

\section{The Differential Management of Financial Illegalisms}

\section{Law and the Legitimacy of Finance}

To what extent does the assignment of responsibility between organizations and individuals by courts and agencies reflect and reproduce the interests of finance? This is the sociological puzzle tackled in this paper.

At the center of this issue lies the relationship between law and the legitimacy of financial capitalism, a question that surprisingly occupies little place in sociology (Preda 2009; Münnich 2015). Talking about the legitimacy of financial capitalism implies that the

${ }^{3}$ It is worth noting that the question of illegality within the financial industry has rarely been tackled in economic sociology (Abolafia 1996; Fligstein and Roehrkasse 2016; Reurink, 2016; Angeletti 2017), and it is often considered a marginal problem (MacKenzie 2011). Indeed, law was a peripheral concern in economic sociology until recently (Stryker 2003; Edelman and Stryker 2005; Beckert and Wehinger 2013). 
ordinary practices of the financial sector are inseparable from the strong, continuous justifications of finance's contributions to the common good. Following Boltanski and Chiapello (2006), I consider, first, that capitalism comes with justifications and second, that it is always subject to critiques. Many phenomena could be studied as contributing to the legitimation of financial capitalism, from the scholarly developments of the "law and economics" approachwhich considers fraud as automatically corrected by markets' selfregulation (Easterbrook and Fischel 1991) - to the proliferation of financial literacy programs.

The involvement of law in particular can be approached from that angle (Montagne 2005). If legal decisions affect the legitimacy of a particular financial organization (Suchman 1995), criminal convictions of banks, for instance, can undermine the legitimacy of the social order banks represent, that is financial capitalism. At an intermediate level, legal decisions can justify or delegitimate the need for a regulation of finance. Law is part of a perpetual field of problematization (Foucault 1985: 37) of finance, that is, the multiple ways that define the place finance should occupy in social life. As an answer to the sociological question I raised abovewhich the Libor case will exemplify-I argue that the strong criminal focus on individuals, more precisely, on mid-level individuals, and the lack of criminal prosecutions for organizations contribute to the protection of financial legitimacy.

\section{A Foucauldian Approach to Fraud}

To advance my argument, I build on a proposal by Michel Foucault in his work on punishment $(1977,2015)$. Foucault argued that legal and extra-legal institutions consider illegal practices differently depending on the types of individuals or entities involved-that there is, in other words, a differential management of illegalisms. To emphasize this distinction, Foucault used the neologism illégalismes. I too will use the term "illegalisms" in what follows. ${ }^{4}$ The term "illegalisms" does not designate only sanctioned or punished actions: in its plural form it designates also actions that are potentially illegal. To become a crime, illegalisms have to be detected, declared to the relevant authorities, investigated thoroughly, prosecuted, judged, and eventually condemned (Gusfield 1981: 136-9). From this perspective, while members of the working class most often face criminal prosecution, elites and organizations have at their disposal a large range of alternative

${ }^{4}$ In the 1977 English translation of Discipline and Punish (Foucault 1977), "illegalisms" was translated as "illegalities"; however, in the recent translation of Foucault lectures on The Punitive Society (Foucault 2015) Foucault's gesture and will to use a neologism was restored. 
procedures that often allow them to avoid criminal prosecution (Sutherland 1983; Lascoumes 1986). Sutherland highlighted this phenomenon in his study of white-collar crime, talking about the differential implementation of the law (Sutherland 1983:53-60).

The differential element in the Foucauldian approach is twofold. In a first sense, it emphasizes social hierarchy: What is differential here is that courts and agencies treat differently the illegalisms of individuals and entities such as organizations, depending on their respective resources, power, and legitimacy. ${ }^{5}$ The advantages of "repeat players" (such as prosecutors and financial organizations) relative to "one-shotters" (in this case traders, even if they are not without resources), to use Galanter's terminology (1974), are often clear in financial cases. In a second sense, this element invites us to ask when a specific public scandal occurs and when some illegalisms end up in a criminal court whether, at the same time, other illegalisms, sometimes of the very same nature, go unpunished or even undetected. Punishing one illegalism is, in that perspective, always tolerating another-which explains why this framework favors comparative studies. The "differential management of illegalisms" approach thus emphasizes what Lascoumes expressed, in a seminal work, as "the relativity of legal qualification" (Lascoumes 1996:16, my translation).

\section{Illegalisms of Rights and Financial Fraud}

Used in recent research in France (Fischer and Spire 2009; Amicelle 2013; Chantraine and Salle 2013), this Foucauldian approach needs, however, to be pushed further, in order, first, to be adapted to the specific case of financial illegalisms and, second, to be fitted to sociological research. One important distinction introduced by Foucault is especially relevant to the study of fraud in the financial sector: this is the distinction between illegalisms of goods and illegalisms of rights (Foucault 1977: 87). While the former phrase designates common crimes—such as theft—associated with the lower social classes, the latter consists of crimes based on rules circumvention-such as fraud-and especially associated with elites and higher classes. Fraud is therefore for "someone for whom wealth is linked to the law. Not that it is subject to the law, but it gives access to the possibility of making and dismantling, of imposing and getting around the law" (Foucault 2015: 148).

The conception of illegalisms of rights is particularly relevant for finance, precisely because finance is legally constructed (Pistor

${ }^{5}$ It is even arguable that financial organizations are more powerful than prosecutors, considering the volume of resources at their disposal: organizations are highly responsive to their legal environments (Edelman and Suchman 1997), and this appears even more true for financial institutions (Black 2013). 
2013). As Pistor has shown, the products that financial actors exchange are, before anything else, legal products. It is because financial products are the result of contracts and rules that illegalisms - of rights-can flourish. In other words, finance appears to be an especially conducive environment for illegalisms of rights. Financialization indeed has contributed to transforming the forms of illegalisms, from illegalisms centered on the circulation of goods to illegalisms centered on the circulation of capital (Calavita, Pontell and Tillman 1997). While the study of such transformations exceeds the scope of this paper, it nevertheless reveals the congruence between the "differential management of illegalisms" approach and the study of financial markets.

\section{How Differential Management Happens}

This congruence between the Foucauldian framework and the study of fraud in financial markets needs to be suited to a sociological approach. Doing so requires specifying the empirical ways through which differential management is actually performed-in our case between two manipulations of Libor-and in that perspective, I distinguish six important dimensions to focus on. I name them as follows: the conflict-resolution devices; the motives; the conceptions of the case; the victims; the types of sanction; and the forms of responsibility. Table 1 sets out these dimensions and provides a roadmap of the empirical analysis of the Libor case.

The emphasis of the "differential management of illegalisms" approach on the variety of institutions that intervene on illegalisms (Foucault 1977: 87) leads us to study a first dimension: the type of devices used to resolve the conflict at hand. What characterizes financial illegalisms, in this respect, is the multiplicity of conflict-resolution devices, especially with the transnationalization of regulation (Bartley 2007; Black 2008). Sociolegal scholarship has shown that the rising use of alternative dispute resolution procedures makes it possible to circumvent the traditional court system (Lascoumes 1986; Edelman 1990; Edelman and Cahill 1998; Talesh 2009, 2012). Following these insights, I approach criminal

Table 1. Summary of the Argument

\begin{tabular}{|c|c|c|}
\hline Dimensions & Trader Manipulation & Lowballing Manipulation \\
\hline $\begin{array}{l}\text { Main Conflict-Resolution } \\
\text { Device }\end{array}$ & Criminal Trials & $\begin{array}{l}\text { Settlements, Especially DPAs } \\
\text { and NPAs }\end{array}$ \\
\hline Motives & $\begin{array}{l}\text { Greed and Excessive } \\
\text { Profit-Seeking }\end{array}$ & $\begin{array}{l}\text { Protecting the Reputation } \\
\text { of Financial Institutions }\end{array}$ \\
\hline Conception of the Case & Libor as Closing Number & Libor as a Sign \\
\hline Victims & Counterparties & Unidentified \\
\hline Type of Sanctions & Jail & Fines and Reforms \\
\hline Main Form of Responsibility & Individual & Collective \\
\hline
\end{tabular}


law as a very specific procedure of conflict resolution: it has to be considered in relation to others, ranging from administrative to internal procedures within the financial industry. In the Libor case, the conflict-resolution devices are mainly criminal trials and settlements-which overlap the focus on individual or on corporate responsibility. An important difference between these devices lies in the burden of proof they each require. In criminal trials, the burden of proving a defendant guilty beyond reasonable doubt is strongly linked to the focus on mens rea-criminal intent - that prevails in white-collar cases (Dervan and Pogdor 2016: 575). The predominance of the criminal intent logic leads to a strong focus on the defendant's state of mind (Dervan and Podgor 2016; Mann 1985). However, evidence that could prove that illegal practices took place are not necessarily the same as evidence that could prove that the defendant had knowledge of the illegal character of his practices. On the contrary, agreements that organizations enter into are not tied by the same requirements concerning burden of proof, and publicly available agreements do not make it possible to fully capture the extent of fraud-while negotiations with prosecutors on such agreements remain private. Furthermore, when entering into such agreements, organizations are often required to provide evidence to the government related to individual wrongdoings of their own employees (Dervan and Podgor 2016: 573), which once more reinforces the opposition between individual and corporate responsibility. While important research has shown that the common law standard is strongly biased toward an individualist conception of liability (Sutton 2011) — a bias that makes it difficult to resolve certain social problems (Pedriana and Stryker 2017) — this orientation is especially relevant to financial cases.

The next dimensions relate to the forms of social categorization that prevail during the legal process. Cicourel's seminal study is especially relevant in that respect, as he focused on the ways in which police and courts categorized defendants, using an idea close to Foucault's: the selective law enforcement (Cicourel 1968). By examining how law enforcement officers applied general policies and rules in particular situations, how they engaged their "sense of the social structure," Cicourel showed that the stereotypes they relied on and their common-sense view of offenders led them to concentrate, in the case of juvenile delinquency, on members of the working class.

Building on these insights, attention must be paid to a second dimension: motives. During the legal process, motives, often moral, are imputed to the actors implicated. These motives differentiate and hierarchize practices-from greed to reputational concerns in the Libor case. This emphasis on social categorization is also 
relevant for a third dimension: the conception of the case at hand. This raises a perspective close to the one adopted by Fourcade on the economic valuation of nature (2011). In our study, the two Libor manipulations come with two underlying conceptions of the rate: Libor is conceived, first, as a closing number that puts an end to a financial transaction with a counterparty; but, second, as a signal sent to other financial actors. This distinction has direct implications, specifically on the conception of the victims-a fourth dimension to consider. Conceiving Libor as a closing number leads to a limitation of the victims to the counterparties of a specific transaction, while conceiving Libor as a signal sent to other financial actors distributes the victims in such a way that they appear to be unidentified.

The fifth dimension is the type of sanctions adopted. In the Libor case and mainly linked to the type of conflict-resolution devices used, sanctions range from jail time for the traders involved and fines for the banks in the first manipulation, to only fines for the banks in the second manipulation.

This, finally, leads us to look closely at a sixth dimension: the forms of responsibility that result from what precedes and which are favored in each case, from individual to a more collective responsibility. In the Libor case, while individuals are identified as the main responsible in the first type of Libor manipulation, responsibility is assigned mostly at the level of the banks in the second type. White-collar crime studies have contributed to this issue, mainly through two perspectives. A first perspective, favored by criminology and usually linked to deterrence, asks whether we should focus on individuals or on corporate prosecutions (Fisse and Braithwaite 1988; Geis and Dimento 1995; Schell-Busey et al. 2016). This question, as relevant as it is for the authorities, is of little help when trying to capture sociologically the process that allows this assignment to exist and to be implemented, as well as to document its consequences. A second perspective builds on a prevalent distinction made in white-collar crime studies between occupational crime and corporate crime (Clinard, Quinney and Wildeman 1994; Braithwaite 1985). While the former points to conduct undertaken to benefit the perpetrator, the latter points to conduct undertaken to benefit the organization. This distinction is important with regard to the assignment of responsibility, and even structures the prosecuting process itself (Dervan and Podgor 2016). However, it implies that the benefit of the misconduct can be attributed to one or the other, which is an especially difficult task considering that some acts can benefit both levels (Wheeler and Rothman 1982: 405). The sociological approach I adopt in this paper asks rather what conditions need to be met to differentiate the responsibility of individuals and organizations. 
These six dimensions (conflict-resolution devices, motives, conceptions of the case, victims, types of sanctions, forms of responsibility) give a sociological grounding to the "differential management of financial illegalisms" approach. Through their study, I show how such management is actually achieved in the legal treatment of the Libor scandal and how the same illegalisms can end up with radically different outcomes. My argument is that the focus on individual or on corporate responsibility is a decisive way for managing financial illegalisms differentially.

\section{The Libor Case}

Libor is a key benchmark in financial markets: it is an interbank rate used by banks to evaluate borrowing possibilities between banks. ${ }^{6}$ Libor was created in the mid-1980s and until 2014 was administered by the British Bankers' Association (BBA), a trade association representing the interests of more than 200 domestic and international banks in Britain. Until the scandal Libor was calculated daily in London for 15 different maturities (from 1 day to 1 year), and for 10 different currencies, including the euro, the dollar, the pound, and the yen. In 2012, the total value of contracts and products linked to Libor was estimated to be $\$ 300$ trillion (Wheatley Review 2012). This figure contains many financial products, including products dedicated to households such as mortgages and student loans.

The calculation of Libor was quite simple. A panel representing between 8 and 16 banks selected by the BBA was asked to answer a standardized question: "At what rate could you borrow funds, were you to do so, by asking for and then accepting interbank offers in a reasonable market size just prior to 11 a.m.?" Being included in these panels was very important for the banks for two reasons. First, the banks selected could influence Libor. Second, they were considered legitimate to pronounce on the situation of the interbank market. The submission of Libor rates by each bank involved a subjective appreciation of the current economic situation. Each rate was based not on past transactions but on the evaluation by an individual within banks: the submitter. On the basis of the information at his disposal, the submitter inferred the rate at which his bank would be able to borrow funds from other banks. Once submitted the rates of all banks, they were ranked: the top and bottom quartiles were ignored, and the mean of the eight remaining rates was calculated to produce the Libor of the day, for the currency and period under

${ }^{6}$ The Libor scandal has been presented in details in a previous publication (Angeletti 2017). 
consideration. Around 11:45 a.m., the BBA published the rates and disseminated it "daily on more than 300,000 screens around the world" (BBA 2008).

The Wall Street Journal reported in 2008 on irregular Libor submissions (Mollenkamp 2008), and criminal investigations into its manipulation began in 2012. Regarding individuals, 27 individuals have been charged for manipulating Libor and 11 for manipulating Euribor, in the United Kingdom and in the United States. Of these 38 individuals-traders, brokers or submitters-12 are awaiting trial, 8 have pleaded guilty, nine have been convicted after trial (with 2 convictions overturned), and 9 have been acquitted. Regarding organizations, 13 financial institutions have received monetary penalties exceeding $\$ 9$ billion from American, British, and European authorities, and investigations continue.

\section{Data and Methods}

To study and understand the legal treatment of the Libor scandal, I collected data from three sources, especially in the United Kingdom and the United States: legal decisions, the ethnography of the trials, and the transcripts of court hearings.

The first source involves legal decisions and reports produced after the revelations of misconduct. I systematically gathered court and agencies' decisions related to the Libor scandal in the United Kingdom and the United States. Regarding first the United Kingdom, I gathered the final decisions of the British financial market regulator, the Financial Services Authority (FSA), related to individuals and to organizations, which the FSA publishes on its Web site. I also gathered the British criminal court decisions of the Libor-related trials, through the Web site of the Serious Fraud Office, the prosecuting authority dedicated to complex fraud in the United Kingdom. Regarding, second, the United States, I operated in a similar way. I collected the decisions of the Commodity Futures Trading Commission, the agency that regulates futures and options markets in the United States, as well as the decisions of the Department of Justice. In the American case, however, I also had to gather the different settlements entered into by the Department of Justice with banks and other financial institutions, through nonprosecution agreement (NPA) and deferred prosecution agreement (DPA). ${ }^{7}$ To keep informed of new decisions and to collect documents, I used Law360, a database that provides news, as well as case law materials. The

7 This type of agreement was introduced in the United Kingdom in 2014, but it was not used in the Libor case. 
decisions identified through Law360 were verified through the relevant regulators and court databases and, for the American criminal cases, through PACER, the document management system for federal courts. To these rulings I added the ones made by the European Commission. In respect of methodology, these documents allowed me to produce a table assembling all the decisions taken by courts and agencies in response to the Libor scandal. For each decision, I noted the accused entities (individual or organization), the charges, the dates of both the actions involved and the decision, the type of device use to achieve a decision (trial, guilty plea, NPA, DPA, etc.), the type of sanction and their content where necessary, and finally the chronological place of each decision in the legal treatment of the scandal as a whole. I added to these first-hand materials the official reports written after the scandal, especially by British institutions as Libor was a Londonbased benchmark. Based on this collection, I engaged in extended qualitative reading and analysis of all the documents gathered, primarily to capture the ways in which responsibility was individualized or, conversely, collectivized at the level of organizations.

The second source involves data collected through an ethnographic investigation of the trial of Tom Hayes, $R v$ Hayes (2015). It was the first criminal trial of a trader for manipulating Libor and it took place in May 2015 at Southwark Crown Court in London, where British financial trials are usually adjudicated. I observed the hearings of this 3-month trial, which usually lasted from 9 a.m. to 5 p.m., with a lunch break. Considering that the trial was open to the public, I did not need special authorization to observe the hearings, and was able to exchange with other individuals attending the trial, mainly journalists and lawyers. This trial provided an especially relevant vantage point to study the ways in which responsibility is assigned in financial cases. Despite a general focus on the social organization of the court and on the sequencing of the trial, which is beyond the scope of this paper, I dedicated particular attention to two dimensions. First, I studied the way prosecutors attempted to individualize responsibility by focusing on the specific actions of the trader or, on his part, to engage the responsibility of his former employers as organizations. These disputes, centered on the role of rules (Angeletti, 2017), gave me a first sense of the two types of manipulation involved in the Libor scandal and of the assignment of responsibilities noticed in its legal treatment, which I pursued by gathering other sources. With regard to this perspective, I looked specifically at the way the intention of the fraud-the mens reawas presented and characterized. Second, I specifically scrutinized the type of evidence advanced, as well as the demonstrations of both defense counselors and prosecutors. In that regard, I paid 
attention to the presentation of Libor by the prosecution and by the academic or financial sector experts called to testify-experts who historically play an important role in the framing of evidence in the common law system (Jasanoff 1995). Ethnography is known to be a methodology especially suited to studying elites and deviance-related phenomena (Katz 1997). In comparison with the use of hearing transcripts, ethnography allows one to capture not only the verbalization of the positions adopted during the trial, but the important nonverbal part. I refer especially to the contestations manifested by parties to the testimonies given or to questions raised, to the reactions of the jury or of the audience, to the physical organization of the court, or to the tangible tensions that were discernible in the courtroom when the issue of the judgment moved closer. Such depth and texture about both the situation and the practices it embodies are unavailable from the study of transcripts alone, which give access in turn to the richness of the debates.

The third source consists of the full official transcripts of hearings of two Libor-related trials: that of Tom Hayes, which I investigated ethnographically, and that of Anthony Allen and Anthony Conti, the first American Libor trial, which took place in the District Court of the Southern District of New York in autumn 2015 (US v Allen, Conti 2015). This court is well known for its engagement in the prosecution of white-collar and financial crime for several decades (Hagan and Nagel 1982). These extended transcripts enrich the analysis developed through my ethnographic investigation and give access to the depth and richness of the debates and disputes in the courtrooms, enabling us to look clearly at how responsibility is assigned between the individual and the organizational level. Regarding trial length, the first trial went on for 47 days and the second for 14 days, which corresponds to 6427 and 1768 pages of transcripts, respectively. I engaged in three different and successive types of reading of these transcripts. A first and complete qualitative reading of the transcripts was dedicated to understanding the dynamics of each trial and especially to identify the moments and debates most relevant for the sociological issue at hand: the assignment of responsibilities. After taking extended notes on the transcripts and selecting the most relevant episodes, a second and more focus reading was dedicated to digging deeper into these key moments of contention, identified through the first reading. I systematically compared such moments between the two trials to identify relevant patterns. Once I had stabilized my main findings, finally I engaged in a third reading of the transcripts to see whether my analysis had changed. This last reading did not raise new 
questions, which convinced me that I had reached saturation in my data collection.

With these data sources as a starting point, my data analysis strategy consisted of looking for patterns in the differential use of categorizations and devices at the individual and at the organizational level, and of identifying and examining the rationales behind this assignment of responsibilities. If I move back and forth between the British and the American case, above the comparative dimension (Fourcade 2011), the predominant opposition that I study and highlight is the one between the responsibility of individuals and of organizations, which appears to be quite similar in both countries.

Limitations need to be mentioned with regard to the data and methodologies used. Studying the legal treatment of the Libor scandal through trials and decisions is, in a way, studying the publicly available part of such legal treatment. Indeed, the discussions within the British Serious Fraud Office, the American Department of Justice, and the financial market regulators are not part of this study, nor are the discussions within organizations during the elaboration of agreements nor those dedicated to selecting which individual would be prosecuted. It has been extensively demonstrated in the literature that prosecutors have discretionary power that allows them to decide whether a prosecution will go ahead, to choose the individuals and organizations who will actually be prosecuted, to select the charges, and to decide where necessary whether a settlement should be proposed (Krug 2002; Dervan and Pogdor 2016). Regarding this discretionary power, an investigation within the offices of these institutions would have been especially interesting; this is a common and well-documented methodological limit in white-collar crime studies (Tombs and Whyte 2007; Lascoumes and Nagels 2014). Nevertheless, in respect of my argument, the study of the publicly available part of the legal treatment of the Libor scandal itself reveals an assignment of responsibility between individuals and organizations.

Finally, with regard to the conclusions that could be drawn from the study of the Libor case (Small 2009), its specificities need to be considered. What is quite peculiar in the Libor case is the implication of several individuals in numerous organizations, thus giving the case a collective dimension-in contrast to "ordinary" embezzlement cases, which only involve "a single individual in a subordinate position against a strong corporation" (Sutherland 1983: 237). This reminds what has been considered the paradigmatic form of white-collar crime in the context of financial capitalism: collective embezzlement (Calavita and Pontell 1991; Calavita, Pontell and Tillman 1997). As these authors have shown from the study of the thrift industry, collective embezzlement involves 
"networks of co-conspirators inside or outside the institution" (Calavita and Pontell 1991: 98). Indeed, one important dimension of the social organization of the financial industry, well-shown by both social studies of finance and financialization scholarship, is its interdependent and reticular character. The daily financial practices in which actors are embedded are closely interrelated, much more than in other areas. The manipulation of a key benchmark in the financial industry, linked to numerous financial products, which constitutes the Libor case, makes it an especially good example for trying to understand both the types of illegalisms that take place in the specific historical form that is financial capitalism and the types of legal response that prevail in this context.

\section{Individuals' and Organizations' Responsibilities: From Trader Manipulation to Lowballing}

Almost from the outset of the Libor scandal, the authorities distinguished between two different types of Libor manipulation: trader manipulation and lowballing. ${ }^{8}$ In the first case, traders were suspected of having influenced Libor submitters to benefit from a rate more favorable to their position on the market: what was officially referred to as trader manipulation. This type of manipulation personalizes the fault and individualizes its benefits. The second case, in contrast, raises the issue of the systemic character of the crisis. Some banks deliberately undervalued their Libor submissions to avoid appearing insolvent: what was officially referred to as lowballing. By publicly declaring that they were not seeking cash at any price, financial institutions indicated their robustness and stability when the threat of an insolvency crisis was looming. While trader manipulation explicitly refers to a given position within a bank's hierarchy (traders), lowballing makes no reference to a position of any sort. Yet lowballing involves a larger view of the situation of the banks and points to a higher level of responsibility in the financial sector hierarchy.

Following the analytical dimensions previously identified and summarized in Table 1 (conflict-resolution devices, motives, conception of the case, conception of the victims, type of sanctions), I detail in the subsequent subsections the underlying conception that prevails in each of these two illegalisms: trader manipulation and lowballing manipulation of Libor. The study of these dimensions elucidates the prevalent forms of responsibility in eachprimarily individual for the former and organizational for the

${ }^{8}$ One of the first documents on the Libor scandal by the British FSA testifies to this distinction (FSA 2012a), as does the important House of Commons report, Fixing Libor: Some Preliminary Findings (House of Commons Treasury Committee 2012). 
latter-thus revealing how financial illegalisms are differentially managed in practice.

\section{Conflict-Resolution Devices: Criminal Trial Versus Settlement}

Trials, and more generally criminal law, are the main devices through which specific individuals' responsibility for the trader manipulation of Libor was assigned. Tom Hayes, 35 years old at the time of the trial, was the first individual judged in a criminal court for manipulating Libor. After graduating in mathematics and engineering at the University of Nottingham, Hayes entered the Royal Bank of Scotland at 21 as a trainee at the interest rate derivatives desk. He became a trader, and joined UBS in 2006 where he worked at the Tokyo office and started trading derivatives. In December 2009, Hayes moved to Citigroup, where, by the spring of 2010, he started to have difficulties. In August 2010, he wrote an email to his direct manager:

Chris, I want to express my concern about the recent meetings with various lawyers, internal and external. I spent numerous hours (approaching eight hours) having discussions with the lawyers about the practice of setting LIBOR. As you are aware, until this week there has been no internal rule or policy surrounding this practice and therefore I'm not really sure why I am repeatedly being dragged off the desk to discuss this. During the various meetings with lawyers I have felt as though perhaps I'm being accused of doing something wrong, although frankly I'm not sure whether that is the case or not. If it is the case, I'm not sure exactly what I am being accused of.... Either way, the reasons for me being called to the long and aggressively conducted meetings with various sets of lawyers is not at all clear to me and this, as I'm sure you can imagine, is causing me considerable stress.

Email presented during $R v$ Hayes (2015), July 7, 2015

A few days later, Citigroup dismissed Hayes. Two years after that, on December 11, 2012, he was arrested in the United Kingdom in connection with the manipulation of Libor and charged a few months later by the British Serious Fraud Office with eight counts of conspiracy to defraud. At trial, he was accused of having attempted to manipulate Libor hundreds of times.

According to the prosecutor, Hayes was the "mastermind of the Libor scandal." The individualizing aspect of the charges against him was yet ambiguous: "conspiracy to defraud" indeed involves a collective dimension. Nevertheless, his specific and leading role in the manipulation was emphasized in various ways. For the prosecutor, the manipulation of Libor was not as 
widespread as it seemed: "It's a myth," he said in his closing statement, "to say that everybody was doing it." By choosing to prosecute only Hayes at the first Libor trial-which correspondingly received significant public attention-the prosecutors reinforced this individualization of responsibility. ${ }^{9}$ In all subsequent criminal trials related to Libor in the United Kingdom and in the United States, there were between two and six defendants.

Against the prosecution's individualizing focus, Hayes made four main arguments in his defense. First, he argued that his attempts to influence Libor-which he admitted-were common knowledge at the banks he had worked at. Second, he argued that his attempts were not always successful, and that the individuals he talked to did not automatically grant his requests. Third, he claimed that his requests to manipulate submissions were "within the range." "The range," an expression that recurred often during the trial, refers to the range of Libor values that submitters could consider legitimate. What from an external point of view could appear arbitrary was justified here as relevant from the internal moral rules-in-use (Vaughan 1996; Jackall 2010). Fourth, he declared that Libor manipulation was customary, and he presented as evidence a UBS "instruction manual" that clearly detailed how to take into account the traders' derivative positions in making Libor submissions. Hayes declared that he was not aware of that guide and argued that it proved that attempts to influence Libor were common, and that he was therefore not acting as a lone individual.

In contrast to the criminal trial, which has been the favored and most debated device for imputing responsibility in the trader manipulation, with its individualistic bias, the main device used for imputing responsibility for lowballing has been the settlement. By settlement, I refer to the spectrum of solutions offered to organizations by the state, including NPAs and DPAs. The origins of these types of settlement date back to the 1930 s, with the Brooklyn Plan, which suspended prosecution of juvenile offenders while they were under supervision (Rackmill 1996). After this period of supervision-usually 2 yearsprosecution was waived if the offender was deemed to have behaved well. Used mainly for first offenders, the deferred prosecution mainly required the juvenile not to engage in any new illegal activities. In the 1990 s, a similar policy was introduced for organizations (Garrett 2014): a device originally designed for individuals who had committed their first offense

${ }^{9}$ Such process takes also place within organizations and upper hierarchy will often push responsibility down the hierarchy line, as the organizational deviance literature have shown (Vaughan 1996; Jackall 2010). 
was applied to organizations, and often to organizations that committed multiple and regular offenses.

What do DPAs and NPAs involve, and how have they been used in the context of Libor? The 2012 NPA with UBS (Department of Justice [DOJ] 2012a) includes an acknowledgement of responsibility, which is not mandatory. The DOJ agreed that it "will not criminally prosecute UBS"; recognized that the bank "conducted a thorough internal investigation" and "cooperated fully"; and indicated that this cooperation played a "particularly significant and favorable" role in the DOJ's decision to agree to an NPA. The agreement, valid for a period of 2 years, enumerates some conditions, including that UBS "shall commit no United States crime whatsoever" and help the DOJ in its investigation, including informing it of the criminal conduct of its employees. UBS was also required not to make any "public statement" that contradicted the agreement, and to pay a $\$ 500$ million fine.

The agreements stemming from the Libor scandal offer few details about the practice of lowballing, and this lack of detail restricts its publicity, conversely, to the long trials related to trader manipulation. Agreements mention the role of specific highranked individuals in the case of lowballing but in a much less individualized way that for the trader manipulation. This is reinforced as lowballing practices are sometimes addressed at the organizational level. Banks are depicted as having agency: for instance, the UBS agreement indicates that "UBS sought to avoid negative media attention and, relatedly, sought to avoid creating an impression that it was having difficulty obtaining funds" (DOJ 2012a: 38). A characteristic of the "illegalism of the privileged", as noted by Foucault, is that it concerns precisely the ones "who evade the law through status, tolerance, or exception" (Foucault 2015: 142).

\section{Motives: Greed Versus Reputational Concerns}

During the legal treatment of the two illegalisms related to Libor-trader manipulation and lowballing-motives were attributed differentially. Motives, attributed by others or the self, are always reconstructed and based on moral categories, as Mills (1940) argued. But motives can be more or less morally charged: while in the trader manipulation, greed is advanced as a moral vice, the motive for lowballing, reputational concerns, appears as a nobler one, as I delineate successively below.

In the criminal trials related to trader manipulation, the attribution of motives is clearly individualized. It requires a close link 
between one's actions and practices, documented through evidence, as an exteriority; one's state of mind, which is especially difficult to attest, as it refers to an interiority; and something that comes from an external point of view, that of a prosecutor, for instance, a moral judgment. These three elements-practices, state of mind, and moral judgment - are usually connected, such that the moral judgment is not made explicitly by an individual, such as the prosecutor, but is a logical consequence of the other two elements and therefore deprived of any personal feeling or consideration. In his opening statement of the first Libor trial, the prosecutor introduced the main motive through which he explained the defendant's behavior: greed.

In a criminal case the prosecution never needs to prove the motive for the crime, but you may think, having heard the evidence, that here the motive was a simple one. It was greed. Mr. Hayes's desire was to earn and to make as much money as he could. The more that he earned for his employers, the more they would value his services and inevitably, he hoped, the more that they would pay him.... Of course all bankers want to maximize their profits. All of us do, do not we? But Mr. Hayes did it in a wholly dishonest way, concerned only with his profits and wholly unconcerned by the fact that he was cheating those with whom he was trading. In his own words, he was greedy. As he himself said to the investigators when he was interviewed, "But the point is," and these are his words, "the point is, you are greedy, you want every little bit of money that you can possibly get because, like I say, that is how you are judged, that is your performance metric." Now the prosecution says that it was that greed that led to his dishonesty on an enormous scale, as you will see in the course of the evidence.

Prosecutor, $R v$ Hayes (2015), May 26, 2015

Since the crisis, greed has frequently been presented as the motive for wrongdoing on the part of financial actors, and used to draw a line between legitimate and illegitimate profits (Münnich 2015). The critique of financial greed here acts as a denunciation of excessive profit seeking, which should always be subordinated to respect for rules and merit. The pursuit of profit is not denounced as such, as the prosecutor makes clear: "All of us do, don't we?" What is denounced is how the defendant, through greed, has breached the fairness of the normal organization of markets: rather than an attack against the society as a whole, it is an attack against the market (Foucault 2015: 110-112). Such arguments were also employed in other Libor trials and agreements. For instance, in the first American 
Libor trial, the prosecutor began her opening statement as follows:

Ladies and gentlemen, Anthony Allen and Anthony Conti were cheating. They were bankers giving themselves and their bank an unfair advantage, continuously, for years, scheming together with others to rig an important, very important worldwide interest rate called LIBOR.... These men exploited and abused that role over and over again to serve their own ends.

Prosecutor, US v Allen, Conti (2015), October 14, 2015

Greed as a motive results by linking the traders' state of mind (maximizing profits) with their personal best interest (receiving a better salary or bigger bonuses), and the practices they employed (manipulating Libor). Part of the prosecution's demonstration therefore resides in focusing on the moment when the individual committed the illegal act, which Fauconnet referred to as "objective responsibility" (Fauconnet 1928, 115, my translation): how, on a specific date and at a specific hour, a trader asked, sometimes repeatedly, a broker or fellow trader to contact Libor submitters to change the final rate to benefit from it. In privileging objective responsibility, other types of explanation, such as the banks' pressure to make more profit, are excluded as too distant from the action involved: elements that are not part of the precise situation are also not part of the explanation.

Such prosecutors and state agencies' focus on objective responsibility comes with another focus on what Fauconnet referred to as "subjective responsibility" (1928: 108, my translation), the state of mind of the individuals involved and their knowledge of the immoral character of their action. Thinking of "cheating" or "rigging Libor" on its own would not be sufficient for criminal charges, but it is still an essential requirement. The principle of mens rea-"guilty mind"-is indeed a central component of criminal responsibility in common law countries, especially in white-collar cases (Dervan and Podgor 2016). In prosecutors' demonstrations, both objective responsibility-actions to manipulate-and subjective responsibility-state of mind inclined toward benefiting from this manipulation-are required to impute a motive on a defendant.

Turning now to the practice of lowballing, I have already established that it did not lead to any trials yet and that organizations chose to settle. If banks' responsibility has mainly been demonstrated through settlements, the motive for lowballing is clearly addressed. For instance, one settlement states that the bank made "inappropriate submissions to avoid negative media comment" (FSA 2012a: 3). It also declares that "Senior management at high 
levels within Barclays expressed concerns over this negative publicity," which resulted in "instructions being given by less senior managers at Barclays to reduce LIBOR submissions in order to avoid negative media comment" (ibid.). Another agreement between UBS and the DOJ addresses the issue of lowballing as well as the issue of reputational harm:

Because a bank's LIBOR contributions, even if they are not based entirely on actual money market transactions, should correspond to the cost at which the bank perceives that it can borrow funds in the relevant market, a bank's LIBOR contributions may be viewed as an indicator of a bank's creditworthiness. If a bank's LIBOR contributions are relatively high, those submissions could suggest that the bank is paying more than others to borrow funds. Thus, a bank could be perceived to be experiencing financial difficulties because lenders were charging higher rates to that bank. (DOJ 2012b: 38).

Lowballing is posed as related to the inferences economic actors could make from UBS's Libor submission: UBS "sought to avoid creating an impression that it was having difficulty obtaining funds" (ibid.). Lowballing took place at a particular time, during the credit crunch, often pictured as generating circumstances: "This [lowballing] occurred in large part owing to the circumstances of the financial crisis and the liquidity conditions in the market at the time" (FSA 2012a: 31). At the same time, many governments gave bailouts to banks, in both Europe and the United States. The committed bailout expenditures until July 2009 represented 41.6 percent of the U.K. GDP (Grossman and Woll 2014: 580 ) and in the summer of 2009 bailout costs exceeded $\$ 1$ trillion in the United States (ibid: 579). The close link between protecting the reputation of an organization, avoiding a trial, and the listing of the organization on a stock market, needs also to be taken into consideration. Indeed, between 2001 and 2012, 58 percent of the organizations that entered into a DPA or an NPA were publicly listed on a U.S. stock exchange. In contrast, of the companies convicted without being offered a DPA or NPA, only 6 percent were listed (Garrett 2014: 47).

In this light, the category of "reputational concerns" appears as a fairly selective motive, for two reasons. First, it is morally much less loaded that the category of "greed" used for the traders, and is presented as a defense mechanism, rather than as an intentional one, without referring explicitly to any economic or profit-seeking motives. Second, the limitation of this categorization is related to what was at stake during the crisis, considering that lowballing was directly related to hiding crucial information with regard to the 
stability of the financial system. For instance, after the acquisition of Bear Stearns by JPMorgan Chase in 2008, UBS announced an additional loss of $\$ 19$ billion as a result of its exposure to the subprime crisis, which led Moody's to downgrade its creditworthiness on the same day. In that regard, the link between credit ratings (Carruthers 2013), Libor submissions, the potential solvency crisis, and lowballing was at the center of the 2007-2008 crisis.

\section{Conception of the Case: Libor as a Closing Number, Libor as a Sign}

Besides the conflict-resolution devices used and the motives put forward in the legal treatment of trader manipulation and lowballing, each illegalism comes with a specific conception of Libor-as a closing number for the former and as a sign for the latter-which I successively analyze below.

To explain first the conception of Libor as a closing numberthe one operating in trader manipulation-let us first consider a type of exchange that was described at length in Hayes's trial: interest rate swaps. Swaps emerged in the early 1980s and became widely diffused; they even contributed to the deregulation of financial markets (Funk and Hirschman 2014). A swap is a financial derivative involving an exchange between two counterparties, for instance, two traders in different banks who agree to trade the same notional sum on a given future date. In interest rate swaps, the two parties' sums on the closing date are determined differently: one party chooses a floating rate (Libor), while the other chooses a fixed rate. Thus the only unfixed parameter of the swap is Libor, and the value of the swap depends on what happens to Libor in the future. What the counterparties are actually swapping is the value of that rate.

On August 24, 2007, Hayes, through UBS, entered into a "rate swap transaction" with a Goldman Sachs employee, with a closing date on August 29, 2008: the traders bet against each other for a date a year in the future. A brokerage company, in this case ICAP, sets up the documents for such trades. Brokers provide the legal basis that allows the transaction to happen. Hayes and his counterparty exchanged 60 billion yen. Hayes chose a fixed rate of 1.08 percent per annum, which involved paying 60 billion Japanese yen at a rate of 1.08 . The counterparty agreed to pay a floating rate-the Libor Japanese yen rate-which involved paying 60 billion Japanese yen at the value of the Libor Japanese yen rate on the closing date. UBS would make a profit if Libor was above 1.08 percent and it would lose money if it was below that. It is mainly in the context of such interest rate swaps that the trader manipulation of Libor occurred. If, in such an exchange, one party managed to influence the only element that could orient the result of the transaction-namely, the Libor on the closing 


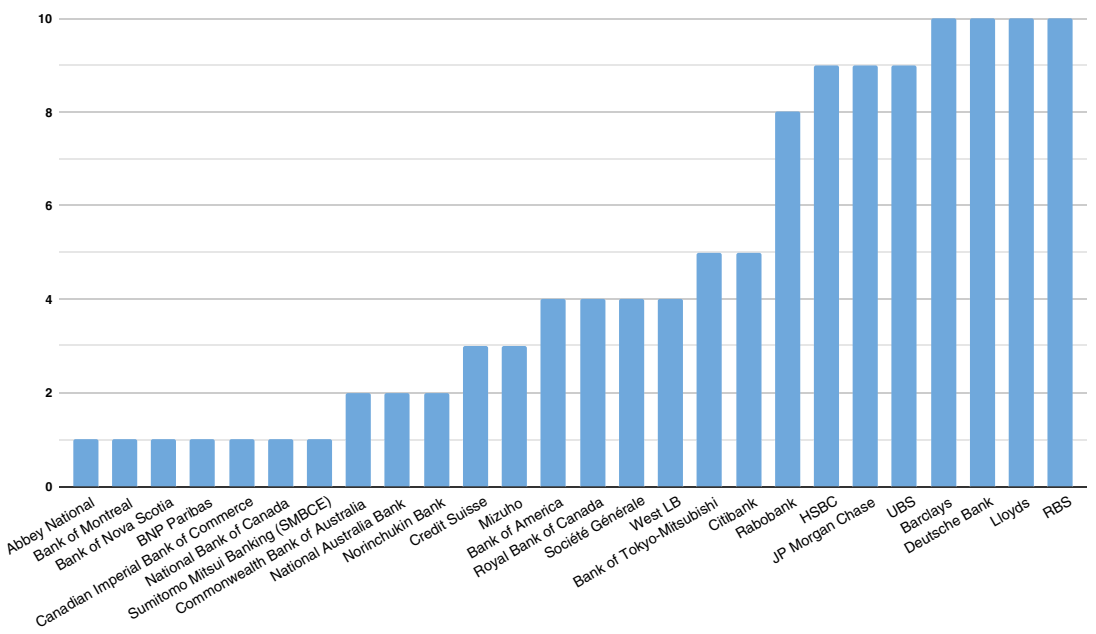

Figure 1. Bank's Participation in Libor Panels June 2009. [Color figure can be viewed at wileyonlinelibrary.com]

date-the result would be affected. This is what Hayes and others were accused of doing.

In the perspective of the trader manipulation, what is Libor and why would someone attempt to manipulate it? Libor is approached and framed as a closing number, and its value is considered relevant only to specific individuals who are parties to specific contracts with specific closing dates. Benchmarks such as Libor "determine the payments," as an academic called as a witness put it during the first American Libor trial. Libor is therefore a way for individuals to gain-and sometimes lose-money from the perspective of someone embedded in financial markets.

In the case of the second illegalism, lowballing, Libor was framed quite differently: it was conceived as a sign-in an almost semiotic sense-sent to other financial actors. To show this, I return to the calculation of Libor before explaining the historical situation of the financial crisis and then examining a specific example of lowballing.

Until the reforms following the scandal, Libor consisted of 150 different rates based on 10 currencies and 15 maturities. The 10 panels managed by the BBA, 1 for each currency, gathered submissions from different banks: on June 1, 2009, 27 banks were on the panels, of which 7 were present on only one panel and 4 were on all 10 (Barclays, Deutsche, Lloyds, and RBS; see Figure 1). Submitters from UBS contributed rates for 9 of the 10 currencies. In other words, banks contributed quite unequally to the submission of Libor rates. The banks that appeared on more panels were also giving information about their own liquidity and creditworthiness. Indeed, because Libor is a benchmark that, through a subjective 
evaluation, indicates the rate at which banks could borrow funds, it has been seen as an indicator of banks' liquidity needs.

Four banks (Barclays, UBS, HBOS, and Société Générale) admitted lowballing - a deliberate underestimation of a Libor submission-that predominately took place during a specific historical situation: the 2007-2008 credit crunch. Liquidity concerns grew during this time with regard to the lending situation in the London market, especially after the collapse of Northern Rock in September 2007. Difficulties in borrowing money in the interbank market led to rising anxiety over the solvency of financial institutions, in particular after the bankruptcy of Lehman Brothers in September 2008 (Swedberg 2010).

In this context of credit scarcity, lowballing involved three dimensions: publicity, reflexivity, and uncertainty. Regarding publicity, it refers not just to the final rates published, but also to the rates submitted by each bank. In the Libor submission process, the rates sent by banks were publicly available, which could lead other banks in particular, but also other economic actors, to infer their liquidity situation. Regarding reflexivity, the submission of the rates involved evaluating the rates that other banks could submit and adapting each submission to this evaluation. Each bank therefore assesses risks through what others are doing and each decision is a sign sent to other participants. No decision can fully resolve the uncertainty of the public unveiling of the results, in the sense that each individual decision is evaluated in relation to the others, in which context "isolation is the worst possible outcome" (Ermakoff 2008: 181). If one bank submitted a higher rate than the other banks, it could be interpreted as an indication that it was having difficulty borrowing funds, and perhaps that it was not creditworthy. If one bank submitted a very low rate, that could also be interpreted as an attempt to hide its difficulties raising funds and appear creditworthy in the eyes of other market actors. Banks attempted to avoid appearing completely misaligned with other banks, as one submitter explained: "the guidance I got from my management with regards to libors is that we should aim to be in the middle of the pack" (FSA 2012b: 25). In another e-mail, a UBS manager said to senior managers: "It is highly advisable to err on the low side with fixings for the time being to protect our franchise in these sensitive markets. Fixing risk and [profit and loss] thereof is secondary priority for now" (FSA 2012b: 20). Lowballing therefore required a high level of reflexivity, in that the submissions were understood to have important potential consequences for the banks. Regarding uncertainty, while for trader manipulation Libor was a closing number relevant only to the present, for lowballing what mattered was future uncertainty. Lowballing was an attempt to reduce this 
uncertainty and to limit the possible inferences related to a bank's situation.

Lowballing, through these dimensions, therefore characterizes the type of critical collective alignment situations in which actors are collectively and individually constrained to make a decision (Ermakoff 2008: especially, 181-210). Libor is here conceived as a sign, because coordination in uncertain situations "means that all those experiencing the same behavioral uncertainty have an interest in forming mutually consistent beliefs about what everyone will do" (ibid: 196).

\section{Victims: Counterparties or Unidentified}

The highlighted conceptions of Libor that prevail in the legal treatment of the two illegalisms have consequences for the conceptualization of victims. Corresponding to the understanding of Libor as a closing number is, first, a conceptualization of victims as restricted to the counterparties to the transactions. Despite the numerous contracts linked to Libor, the victims of the trader manipulation are presented restrictively as the counterparties of the transactions involving the individuals charged and sued. For instance, during the first American trial, the prosecutor presented the victims as follows:

The counterparties included banks, large and small, and private companies, worldwide, and right here in the United States. The essence of these swaps is that you have folks who will make money on one side and lose money on the other. So if the defendants are gaining because they aren't playing the game fairly, you'll have folks losing on the other side.

Prosecutor, US v Allen, Conti (2015), October 14, 2015

This understanding of the victims of trader manipulation of Libor is also present in the settlement agreements between state agencies and banks: "In the instances when the published benchmark interest rates were manipulated in UBS's favor due to UBS's manipulation of its own or any other Contributor Panel bank's submissions, that manipulation benefited UBS derivatives traders, or minimized their losses, to the detriment of counterparties" (DOJ 2012a: 36).

But while the victims in trader manipulation were conceptualized as counterparties, they remained unidentified in legal proceedings regarding lowballing. By positing "avoiding negative media" as a motive, without any reference to direct economic motives, the legal treatment of lowballing presents financial institutions' behavior as a defensive reaction rather than clear and 
intentional action. The conception of Libor as a sign leads to an un-identification of victims, as if this illegalism did not harm anyone directly, which is consistent with the absence of calculation of the full effects of Libor manipulation by regulators (Ashton and Christophers 2015). There is no need to identify victims in these procedures, as in the ones dedicated to the trader manipulation, but it could have helped individuals and corporations mobilize not only to claim their rights but to critique the financial industry. This absence also shows the difficulties of making visible the victims of financial fraud, who are most commonly presented as diffuse.

\section{The Sanctions: From Jail to Fines and Reforms}

I have shown so far that for trader manipulation, the pursuit of justice is framed as involving dishonest individuals' behavior, while, for lowballing, it is framed as relevant to the protection of banks' reputations, without a direct economic purpose. This has revealed law as an "instance of arbitration between illegalisms" (Foucault 2015: 146). To complete the comparison between two illegalisms of the same nature-the manipulation of a financial benchmark-I turn, finally, to the sanctions they generated.

Regarding trader manipulation, not all trials resulted in a conviction. The second Libor trial in the United Kingdom $(R v$ Read et al. 2015) resulted in the acquittal of the five defendants, while the third ( $R v$ Johnson et al. 2016), involving six defendants, resulted in the conviction of four and a hung jury for the other two, who were found not guilty at their 2017 retrial. In most cases resulting in conviction, the defendants were sentenced to jail. Hayes received the most severe sentence: 14 years, reduced to 11 on appeal. Since that decision, he has asked the Criminal Cases Review Commission to review his conviction and a decision is pending. While traders have been pursued for trader manipulation through criminal law, institutions have also signed agreements and paid fines.

Regarding lowballing, only two individuals have been charged, and while there were no criminal trials against financial institutions, the settlements included some form of sanctions. Most of these agreements make reference to both trader manipulation and lowballing (for instance, DOJ 2012a), as a result of which it is difficult to completely determine the extent to which these fines were levied. DPAs or NPAs usually contain three unequally represented conditions: a fine, the transformation of corporate governance, and the introduction of independent experts in the boardroom. Regarding monetary penalties, UBS paid the DOJ $\$ 500$ million, Barclays $\$ 160$ million, and in total fines exceeded $\$ 9$ billion. But what is striking about Libor-related DPAs and NPAs is that they scarcely refer to the 
internal reforms the organizations are supposed to make. One would think that such agreements, made between the DOJ and large financial firms, usually after several years of investigation, would describe the reforms required in significant detail. If they are mentioned at all, these reforms seem to be left to the discretion of the firms. One agreement states that "It is further understood that, as noted above, UBS has strengthened its compliance and internal controls standards and procedures, and that it will further strengthen them" (DOJ 2012b). This succinct statement resonates with the fact that courts are usually unable to verify the effectiveness of these reforms (Krawiec 2005; Garrett 2014). Yet, of the 255 DPAs and NPAs signed in the United States between 2001 and 2012, 63 percent required a new compliance program (Garrett 2014: 48). The requirement for more internal compliance structures is part of a larger movement of endogeneity of law within the financial industry (Edelman 2016: 226-229), even if internal compliance structures can be merely cosmetic and aimed at reducing organizational liability (Krawiec 2005).

\section{Conclusion}

One major political question in recent years, as well as an enigma for social scientists, has been how finance has maintained its legitimacy after the crisis of 2007-2008. To provide a sociological explanation, this paper advanced a Foucauldian frameworkthe differential management of financial illegalisms-and studied the much-debated Libor scandal. It showed that the assignment of responsibility between individuals and organizations, by courts and agencies, contributes to reflect and reproduce the interests of finance. Such assignment is not so much a precondition of legal treatment, but rather a product of it through the use of devices and categorizations. In that respect, it is not only the outcomes of the legal treatment that are important here, but the very process that allows the differential management.

The comparison of two illegalisms, trader manipulation and lowballing, has revealed a strong differential management. In the case of lowballing, the major focus on the responsibility of companies circumvents the prosecution of high-ranking individuals, even if the type of practices involved is most likely to require a global view of the company. In his seminal paper on corporate punishment, Coffee (1981) quoted Lord Chancellor of Great Britain Edward Thurlow: "Did you ever expect a corporation to have a conscience, when it has no soul to be damned, and no body to be kicked?" The use of settlements prevents from bringing to the 
light of public knowledge-and correlatively of public debatethe extent of the practices involved in lowballing, even if their systemic and collective consequences are highlighted. The legitimacy of financial markets is here spared through omission. By contrast, the legal treatment of trader manipulation is much more focused on the role of individuals and takes place on a public scene. The public extent to which trader manipulation has been debated seems to have faded out lowballing, as if the Libor scandal was limited to the former. One of the social functions of such individualization of responsibilities is scapegoating: putting the responsibility on an individual to protect the legitimacy of a social organization, here the financial sector. The legitimacy of financial markets is here spared through exclusion. This phenomenon is anything but new: noxal surrender played a similar role in the seventeenth century. Originating in Roman law, noxal surrender involved "abandoning" a family member to the victim. For instance, if a family member or animal belonging to that family committed an offense, the head of the family could avoid conviction by delivering the perpetrator to the victim. "The main function of noxal surrender is to release the family from collective responsibility" (Fauconnet 1928: 67, my translation).

Releasing finance from collective responsibility brings me back to the original question of this paper, the legitimacy of financial capitalism and its relationship to law. In his famous writing on the law on thefts of wood, Karl Marx has shown how law can contribute to extending the capitalist logic to practices previously out of reach as well as maintain the forms of domination that capitalism not only develops but builds on (Marx 2010). Legal proceedings, coming from a modern state claiming to serve general interest, define for Marx which illegalisms are tolerated and which ones are repressed. Accordingly, individualization of responsibilitynot limited to finance (Vaughan 1996; Jackall 2010)—is a legal solution to avoid the interrogation of the functioning of a particular system. Such individualization rests upon the form of responsibility that prevails in criminal law, which implies criminal intent: financial fraud, rather than looked at as a systemic problem, here becomes a question of individual dishonesty. In that respect, another particularly relevant conception of liability, promoted in the wake of the civil rights movement, emphasizes rather than intent the consequences of a particular action (Sutton 2001; Pedriana and Stryker 2017). While the criminal conception of liability, with its focus on intent, is directed toward the individual, the strict standard of liability, through the research into consequences, is directed toward the collective. Such a standard could suggest a radically different view of what financial fraud implies: approaching it through its effects could more clearly reveal the 
interdependency and ramifications of financial activities and therefore contribute to a broader public and critical debate on the place that finance assumed over the course of a few decades.

Although essential, law is not the only scene in which responsibility is forged. The daily production of responsibility results from legal proceedings, certainly, but it is mostly a heterogeneous assemblage in which such proceedings need to be considered in relation to the changes occurring in state policies and regulations, legal theory, social movements and critiques, scientific developments, or inequalities. Paying attention to these dimensions enables us to outline further ways of studying the assignment of responsibility in the specific case of finance. First, because white-collar crime research grew within industrial capitalism (Calavita and Pontell 1991) and with analytical tools and findings mostly adapted to this historical form, it undervalued the specificity of illegalisms in the context of financial capitalism. Linking closely the study of financial fraud to the historical process of financialization, as identified by economic sociology (Krippner 2011; Van der Zwan 2014), should be a necessary step in that direction. Second, financial cases often involve economic devices and practices embedded in economic theory, as social studies of finance have shown (MacKenzie 2011). Considering that those economic theories most often adopt an individualistic perspective, further research could pertinently unravel how this individualization is congruent with the requirements of criminal proceedings. Third and finally, it invites us to go back to the practical making of profit within the financial industry which, here again, adopts a much more individualized form than in other activities (Godechot 2017).

Continuing these tasks implies adopting a theoretical framework able to capture the specificity of illegalisms in the context of capitalism, and even more to consider illegalisms as a consistent part of financial capitalism. The differential management of financial illegalisms approach outlined in this paper is intended as a contribution to this aim, by drawing attention to what Foucault (2015: 6) has called the "subtle tactics of sanction".

\section{References}

Abolafia, Mitchel Y. (1996) Making Markets: Opportunism and Restraint on Wall Street. Cambridge: Harvard Univ. Press.

Amicelle, Anthony (2013) "Deux Attitudes Face au Monde': La Criminologie à L'épreuve des Illégalismes Financiers," 94-95-96 Cultures E̊ Conflits 65-98.

Angeletti, Thomas (2017) "Finance on Trial: Rules and Justifications in the Libor Case," 58 European J. of Sociology 113-41.

Ashton, Philip \& Brett Christophers (2015) “On Arbitration, Arbitrage and Arbitrariness in Financial Markets and their Governance: Unpacking LIBOR and the LIBOR Scandal," 44 Economy and Society 188-217. 
Bartley, Tim (2007) "Institutional Emergence in an Era of Globalization: The Rise of Transnational Private Regulation of Labor and Environmental Conditions," 113 American J. of Sociology 297-351.

British Bankers' Association (BBA) (2008) "Understanding the Construction and Operation of BBA LIBOR-Strengthening for the Future".

The Boston Consulting Group (BCG) (2017) Staying in the Course of Banking. Report on Global Risk, March 2017.

Beckert, Jens \& Frank Wehinger (2013) "In the Shadow: Illegal Markets and Economic Sociology," 11 Socio-Economic Rev. 5-30.

Bell, Brian \& John Van Reenen (2013) "Bankers and Their Bonuses," 124 The Economic J. F1-F21.

Black, Julia (2008) "Constructing and Contesting Legitimacy and Accountability in Polycentric Regulatory Regimes," 2 Regulation \& Governance 137-64.

- (2013) "Seeing, Knowing and Regulating Financial Markets," in 24 LSE Law, Society and Economy Working Paper. London School of Economics.

Boltanski, Luc \& Eve Chiapello (2006) The New Spirit of Capitalism. New York, NY: Verso.

Braithwaite, John (1985) “White Collar Crime," 11 Annual R. of Sociology 1-25.

Bron, Jean-Stéphane (2010) Cleveland Versus Wall Street.

Calavita, Kitty \& Henry N. Pontell (1991) “'Other's People's Money’ Revisited: Collective Embezzlement in the Savings and Loan and Insurance Industries," 38 Social Problems 94-112.

Calavita, Kitty, Henry N. Pontell, \& Robert H. Tillman (1997) Big Money Crime: Fraud and Politics in the Savings and Loan Crisis. Berkeley, CA: Univ. of California Press.

Carruthers, Bruce (2013) "From Uncertainty Towards Risk: The Case of Credit Ratings," 11 Socio-Economic Rev. 525-51.

Chantraine, Gilles \& Grégory Salle, eds. (2013) "La délinquance en col blanc : études de cas," X Champ pénal/Penal field.

Cicourel, Aaron V. (1968) The Social Organization of Juvenile Justice. New York, NY: Wiley \& Sons.

Clinard, Marshall R., Richard Quinney, \& John Wildeman (1994) Criminal Behavior Systems: A Typology. Cincinnati, OH: Anderson.

Coffee, John C. Jr. (1981) "No Soul to Damn: No Body to Kick: An Unscandalized Inquiry into the Problem of Corporate Punishment," 79 Michigan Law Rev. 386-459.

Dervan, Lucian E. \& Ellen S. Podgor (2016) "Investigating and Prosecuting WhiteCollar Criminals," in Van Slyke, Shanna R., Michael L. Benson, \& Francis T. Cullen, eds., Oxford Handbook of White-Collar Crime. Oxford, UK: Oxford University Press. 561-81.

Department of Justice (DOJ), (2012a) UBS Non-Prosecution Agreement December 19, 2012.

- (2012b) UBS Statement of Facts, December 19, 2012.

Easterbrook, Frank H. \& Daniel R. Fischel (1991) The Economic Structure of Corporate Law. Cambridge, UK: Harvard Univ. Press.

Edelman, Lauren B. (1990) "Legal Environments and Organizational Governance: The Expansion of Due Process in the American Workplace," 95 American J. of Sociology 1401-40.

(2016) Working Law: Courts, Corporations, and Symbolic Civil Rights. Chicago, IL: Univ. of Chicago Press.

Edelman, Lauren B. \& Mia Cahill (1998) "How Law Matters in Disputing and Dispute Processing, or the Contingency of Legal Matter in Alternative Dispute Resolution," in Garth, Bryant G. \& Austin Sarat, eds., How Does Law Matters? Evanston, IL: Northwestern University Press. 15-44.

Edelman, Lauren B. \& Mark C. Suchman (1997) "The Legal Environments of Organizations," 23 Annual Rev. of Sociology 479-515. 
Edelman, Lauren B. \& Robin Stryker (2005) "A Sociological Approach to Law and the Economy," in Smelser, Neil. J. \& Richard Swedberg, eds., Handbook of Economic Sociology, 2nd ed. Princeton, NJ: Princeton Univ. Press. 527-51.

Ermakoff, Ivan (2008) Ruling Oneself out: A Theory of Collective Abdications. Chicago, IL: Chicago Univ. Press.

Fauconnet, Paul (1928) La Responsabilité. Paris, Alcan: Étude de Sociologie.

Fischer, Nicolas, \& Alexis Spire, eds., (2009) "État et Illégalismes," 87 Politix.

Fisse, Brent \& John Braithwaite (1988) "The Allocation of Responsibility for Corporate Crime: Individualism, Collectivism and Accountability," 11 Sydney Law Rev. $468-513$.

Fligstein, Neil \& Alexander Roehrkasse (2016) "The Causes of Fraud in Financial Crisis of 2007 to 2009: Evidence from the Mortgage-Backed Securities Industry," 81 American Sociological Rev. 617-43.

Foucault, Michel (1977) Discipline and Punish. New York, NY: Pantheon. (1985) History of Sexuality, Vol. 2, The Use of Pleasure. New York, NY: Pantheon. (2015) The Punitive Society: Lectures at the Collège de France, 1972-1973. New York, NY: Palgrave Macmillan.

Fourcade, Marion (2011) "Cents and Sensibility: Economic Valuation and the Nature of 'Nature," 116 American J. of Sociology 1721-77.

Financial Services Authority (FSA), (2012a) Barclays Final Notice, FSA 122702, June 27, 2012.

- (2012b) UBS Final Notice, FSA 186958, December 19, 2012.

Funk, Russel J. \& Daniel Hirschman (2014) "Derivatives and Deregulation: Financial Innovation and the Demise of Glass-Steagall," 59 Administrative Science $Q$. 669-704.

Galanter, Marc (1974) "Why the 'Haves' Come out Ahead: Speculations on the Limits of Legal Change," 9 Law छ Society Rev. 95-160.

Garrett, Brandon L. (2014) Too Big to Jail: How Prosecutors Compromise with Corporations. Cambridge, UK: The Belknap Press of Harvard University Press.

(2016) "The Rise of Bank Prosecutions," 126 The Yale Law J. Forum.

Geis, Gilbert \& Joseph Dimento (1995) "Should we Prosecute Corporations and/or Individuals?" in Pearce, Frank \& Lauren Snider, eds., Corporate Crime: Contemporary Debates. Toronto, Canada: University of Toronto Press. 72-86.

Godechot, Olivier (2001) Les Traders: Essai de Sociologie des Marchés Financiers. Paris: La Découverte.

- (2012) "Is Finance Responsible for the Rise in Wage Inequality in France?" 10 Socio-Economic Rev. 1-24.

- (2017) Wages, Bonuses and Appropriation of Profit in the Financial Industry: The Working Rich. New York, NY: Routledge.

Grossman, Emiliano \& Cornelia Woll (2014) "Saving the Banks: The Political Economy of Bailouts," 47 Comparative Political Studies 574-600.

Gusfield, Joseph R. (1981) The Culture of Public Problems: Drinking-Driving and the Symbolic Order. Chicago, IL: University of Chicago Press.

Hagan, John L. \& Ilene H. Nagel (1982) "White-Collar Crime, White-Collar Time: The Sentencing of White-Collar Offenders in the Southern District of New York," 20 American Criminal Law Rev. 259-90.

House of Commons Treasury Committee (HCTC) (2012) Fixing Libor: Some Preliminary Findings, Vol. 1. HC 481-I.

Jackall, Robert (2010) Moral Mazes: The World of Corporate Managers. Oxford, UK: Oxford Univ. Press.

Jasanoff, Sheila (1995) Science at the Bar: Law, Science, and Technology in America. Cambridge, UK: Harvard Univ. Press.

Krawiec, Kimberly (2005) "Organizational Misconduct: Beyond the Principal-Agent Model,” 32 Florida State University Law Rev. 571-615. 
Lascoumes, Pierre (1986) Les Affaires ou L'art de Lombre: Les Délinquances Économiques et Financières et Leur Contrôle. Paris: Le Centurion.

- (1996) "Lillégalisme, Outil D’analyse," 3 Sociétés \& Représentations 78-84.

Lascoumes, Pierre \& Carla Nagels (2014) Sociologie des Élites Délinquantes. De la Criminalité en Col Blanc à la Corruption Politique. Paris: Armand Colin.

Katz, Jack (1997) “Ethnography's Warrants," 25 Sociological Methods and Research 391-423.

Krippner, Greta R. (2011) Capitalizing on Crisis: The Political Origins of the Rise of Finance. Cambridge, UK: Harvard University Press.

Krug, Peter (2002) "Prosecutorial Discretion and its Limits," 50 American J. of Comparative Law 643-64.

MacKenzie, Donald (2011) "The Credit Crisis as a Problem in the Sociology of Knowledge," 116 American J. of Sociology 1778-841.

Mann, Kenneth (1985) Defending White Collar Crime: A Portrait of Attorneys at Work. New Haven, CT: Yale University Press.

Martin, Randy (2002) Financialization of Daily Life. Philadelphia, PA: Temple Univ. Press.

Marx, Karl (2010) "Debates on the Law on Thefts of Wood," in Karl Marx \& Frederik Engels, Collected Works, 1. New York, NY: Lawrence \& Wishart. 224-263.

Mills, Charles W. (1940) "Situated Actions and Vocabularies of Motive," 5 American Sociological Rev. 904-13.

Mollenkamp, Carrick (2008) "Libor Fog: Bankers Cast Doubt on Key Rate Amid Crisis," Wall Street J. April 16, 2008.

Montagne, Sabine (2005) "Pouvoir Financier vs Pouvoir Salarial. Les Fonds de Pension Américains: Contribution du Droit à la Légitimité Financière," 60 Annales Histoire, Sciences Sociales 1299-325.

Münnich, Sascha (2015) "Thieves, Fools, Fraudsters, and Gamblers? The Ambivalence of Moral Criticisim in the Credit Crunch of 2008," 56 European J. of Sociology 93-118.

National Commission on the Causes of the Financial and Economic Crisis in the United States (NC), (2011) The Financial Crisis: Inquiry Report.

Pedriana, Nicholas \& Robin Stryker (2017) "From Legal Doctrine to Social Transformation? Comparing US Voting Rights, Equal Employment Opportunity, and Fair Housing Legislation," 123 American J. of Sociology 86-135.

Pistor, Katharina (2013) "A Legal Theory of Finance," $41 \mathrm{~J}$. of Comparative Economics 315-30.

Pontell, Henry N., William K. Black, \& Gilbert Geis (2014) "Too Big to Fail, Too Powerful to Jail? On the Absence of Criminal Prosecutions after the 2008 Financial Meltdown," 61 Crime, Law and Social Change 1-13.

Preda, Alex (2009) Framing Finance: The Boundaries of Markets and Modern Capitalism. Chicago, IL: Univ. of Chicago Press.

Rackmill, Stephen J. (1996) "Printzlien's Legacy, the 'Brooklyn Plan,' a.k.a. Deferred Prosecution," 60 Federal Probation 8-15.

Rakoff, Jed S. (2014) "The Financial Crisis: Why Have No High-Level Executives Been Prosecuted?" New York Rev. of Books January 9.

Reurink, Arjan (2016) “'White-Collar Crime': The Concept and its Potential for the Analysis of Financial Crime," 57 European J. of Sociology 385-415.

Schell-Busey, Nathalie, Sally S. Simpson, Melissa Rorie, \& Mariel Alper (2016) "What Works? A Systematic Review of Corporate Crime Deterrence," 15 Criminology \& Public Policy 387-416.

Serverin, Evelyne, Pierre Lascoumes, \& Thierry Lambert (1987) Transactions et Pratiques Transactionnelles. Paris: Economica.

Small, Mario Luis (2009) "How Many Cases Do I Need? On Science and the Logic of Case Selection in Field-Based Research," 10 Ethnography 5-38.

Snider, Lauren (2011) "The Conundrum of Financial Regulation: Origins, Controversies, and Prospects," 7 Annual Rev. of Law and Social Science 121-37. 
Stryker, Robin (2003) "Mind the Gap: Law, Institutional Analysis and Socioeconomics," 1 Socio-Economic Rev. 335-67.

Suchman, Mark C. (1995) "Managing Legitimacy: Strategic and Institutional Approaches," 20 Academy of Management Rev. 571-610.

Sutherland, Edwin H. (1983) White Collar Crime, the Uncut Version. New Haven, CT: Yale University Press.

Sutton, John R. (2001) Law/Society: Origins, Interactions, and Change. Thousand Oaks, CA: Sage.

Swedberg, Richard (2010) "The Structure of Confidence and the Collapse of Lehman Brothers," in Lounsbury, Michael \& Paul M. Hirsch, eds., Markets on Trial: The Economic Sociology of the U.S. Financial Crisis: Part A, Research in the Sociology of Organizations, Vol. 30A. Emerald Group Publishing. 71-114.

Talesh, Shauhin A. (2009) "The Privatization of Public Legal Rights: How Manufacturers Construct the Meaning of Consumer Law," 43 Law E Society Rev. $527-62$.

- (2012) "How Dispute Resolution System Design Matters: An Organizational Analysis of Dispute Resolution Structures and Consumer Lemon Laws," 46 Law \& Society Rev. 463-96.

Tombs, Steve \& Dave Whyte (2007) "Researching White-Collar and Corporate Crime in an Era of Neo-Liberalism," in Pontell, Henry N. \& Gilbert Geis, eds., International Handbook of White-Collar and Corporate Crime. New York, NY: Springer. $125-47$.

Van der Zwan, Natascha (2014) "Making Sense of Financialization," 12 Socio-Economic Rev. 99-129.

Vaughan, Diane (1996) The Challenger Launch Decision: Risky Technology, Culture, and Deviance at NASA. Chicago, IL: University of Chicago Press.

Volscho, Thomas W. \& Nathan J. Kelly (2012) "The Rise of the Super-Rich: Power Resources, Taxes, Financial Markets, and the Dynamics of the Top 1 Percent, 1949-2008," 77 American Sociological Rev. 79-700.

Wheatley Review (2012) The Wheatley Review of LIBOR: Final Report. London, UK: HM Treasury.

Wheeler, Stanton \& Mitchell L. Rothman (1982) "The Organization as Weapon in White-Collar Crime," 80 Michigan Law Rev. 1403-26.

\section{Cases Cited}

Kerviel (2010) “T.G.I. Paris, October 5, 2010,” LCP 42.

$R v$ Adoboli [2012].

$R v$ Hayes [2015].

$R$ v Johnson, Mathew, Contogoulas, Merchant, Pabon, Reich [2016].

$R v$ Read, Goodman, Wilkinson, Farr, Gilmour, Cryan, [2015].

SEC v Tourre, 10 Civ. 3229 (2010).

U.S.v Allen, Conti, No. 1:14-cr-00272-JSR (2015).

Thomas Angeletti is a Research Fellow at the Centre national de la recherche scientifique (Université Paris Dauphine, IRISSO). He previously worked on the role of economics in the making of economic policies. His current research combines economic sociology and sociology of law and focuses on the ways white-collar crime and financial crime are handled in contemporary capitalist societies. 